\title{
Súlyos epilepsziás encephalopathia hátterében azonosított MECP2-gén-mutáció fiúbetegben
}

\author{
Düh Adrienn dr. ${ }^{1}$ - Till Ágnes dr. ${ }^{1}$ - Bánfai Zsolt ${ }^{1,2}$ - Hegyi Márta dr. ${ }^{3}$ \\ Melegh Béla dr. ${ }^{1,2}$. Hadzsiev Kinga dr. ${ }^{1,2}$ \\ ${ }^{1}$ Pécsi Tudományegyetem, Általános Orvostudományi Kar, Klinikai Központ, Orvosi Genetikai Intézet, Pécs \\ ${ }^{2}$ Pécsi Tudományegyetem, Szentágothai János Kutatóközpont, Pécs \\ ${ }^{3}$ A Magyarországi Református Egyház Bethesda Gyermekkórháza, Budapest
}

\begin{abstract}
A szerző́k egy negatív családi anamnézisű, súlyos, neonatalis kezdetú epilepsziás encephalopathiában szenvedő, jelenleg kétéves fiúgyermek esetét mutatják be. A terápiarezisztens epilepszia és az igen súlyos fejlődésbeli elmaradás etiológiáját kiterjedt klinikai vizsgálatokkal sem sikerült tisztázni. Genetikai okot feltételezve, külföldi genetikai laboratóriumban 128 gént tartalmazó újgenerációs szekvenálási (NGS-) panelvizsgálatot indikáltak epilepsziás encephalopathiát okozó betegségek irányában. A vizsgálat egy eddig ismeretlen hemizigóta misszensz mutációt igazolt a MECP2-génben. A szerzők az esetbemutatás kapcsán áttekintik a lányokban klasszikusan Rett-szindrómát okozó, a MECP2-gén mutációi által előidézett idegfejlődési rendellenességek spektrumát fiúkban. Más, X-hez kötött domináns öröklődésú betegségekhez hasonlóan sokáig úgy gondolták, hogy a MECP2-gén-mutációt hordozó fiúmagzatok életképtelenek, napjainkra azonban ez a nézet megváltozott. A szerzők úgy tudják, hogy betegük az első magyar fiúgyermek, akinél a $M E C P 2$-gén mutációja igazolódott.
\end{abstract}

Orv Hetil. 2019; 160(51): 2036-2039.

Kulcsszavak: $M E C P 2$-gén, Rett-szindróma, újgenerációs szekvenálás, epilepsziás encephalopathia

\section{MECP2 mutation in a male patient identified in the background of severe epileptic encephalopathy}

\begin{abstract}
Here we report on a severe, neonatal onset epileptic encephalopathy manifested in a currently 2 -year-old boy with no family history of neurological disease. Extensive clinical investigations were unable to clarify the etiology of the infant's condition characterized by drug-resistant seizures and markedly delayed developmental skills. As in this class of disorders a genetic cause might be identified, a next-generation sequencing (NGS) epilepsy panel examination consisting of 128 genes was initiated for a correct diagnosis. The genetic analysis identified a previously undescribed hemizygous missense mutation in the MECP2 gene. Similarly to other, X-linked dominant disorders, Rett syndrome was originally hypothesized to be lethal in males. This theory, however, has been revised. The aim of this report is to review the wide spectrum of neurodevelopmental diseases observed in male patients carrying mutations in the MECP2 gene classically associated with Rett syndrome in girls. To the author's knowledge, this is the first report in Hungary to document MECP2 mutation of a male patient diagnosed by molecular genetic testing.
\end{abstract}

Keywords: MECP2 gene, Rett syndrome, next-generation sequencing, epileptic encephalopathy

Düh A, Till Á, Bánfai Zs, Hegyi M, Melegh B, Hadzsiev K. [MECP2 mutation in a male patient identified in the background of severe epileptic encephalopathy]. Orv Hetil. 2019; 160(51): 2036-2039.

(Beérkezett: 2019. április 30; elfogadva: 2019. május 24.)

\section{Rövidítések}

DNS = dezoxiribonukleinsav; EDTA = etilén-diamin-tetraecetsav; $\mathrm{EEG}=$ elektroencefalográfia; $M E C P 2=($ methyl $-\mathrm{CpG}$ binding protein 2) metil-citozin-foszfát-guanin kötő fehérje-2;
$\mathrm{MR}=$ (magnetic resonance) mágneses rezonancia; $\mathrm{NGS}=$ (next-generation sequencing) újgenerációs szekvenálás; PCR = (polymerase chain reaction) polimeráz-láncreakció; VUS $=($ variant with unknown significance) ismeretlen jelentőségú variáns 
A Rett-szindróma súlyos idegfejlődési rendellenesség, melynek legfőbb jellemzője a kezdetben teljesen normális ütemben zajló pszichomotoros fejlődést követő szignifikáns regresszió az addig elsajátított képességek területén, beleértve főként a motoros funkciókat, a kommunikációs készséget/beszédfejlődést és az akaratlagos kézmozgásokat. A szindrómát elsőként Andreas Rett osztrák gyermekneurológus írta le 1966-ban. A Rettszindróma volt az első pervazív fejlődési zavar, melynek hátterében genetikai okot sikerült azonosítani 1999-ben. A típusos Rett-szindróma több mint 95\%-ban, míg az atípusos Rett-szindróma több mint 75\%-ban a MECP2gén valamelyik mutációjára vezethető vissza [1].

Az X-kromoszómán elhelyezkedő, mindössze 4 exont tartalmazó MECP2-gén a pleiotrop MECP2-fehérjét kódolja, mely jelentős mennyiségben expresszálódik az agyszövetben, szabályozza a kromatinszerkezetet és a génexpressziót, interakcióba lép egyéb koregulátor transzkripciós fehérjékkel, továbbá kulcsfontosságú epigenetikai modulátor a DNS-metilációban és a hisztonacetilációban betöltött funkciója révén. A neuronalis fejlődésben betöltött szerepének pontos mechanizmusa még nem teljesen tisztázott, az azonban jól ismert, hogy mind a MECP2-gén hiánya, mind fokozott expressziója egyértelmúen károsítja a neuronalis fejlődést [2, 3]. Fontos szerepet tölt be a dentritikus arborizációban, a MECP2-gén mutációja esetén jelentősen megváltozik a dendritsejtek morfológiája, csökken a dentrittüskék száma és átméróje is. Hasonló megfigyelést írtak le a $M E C P 2$-gén fokozott expressziója esetén is, ami jól szemlélteti, milyen érzékenyen vesz részt a $M E C P 2$-gén az idegrendszeri folyamatok szabályozásában [4].

Korábban azt feltételezték, hogy a MECP2-gént érintő mutációk - hasonlóan a legtöbb, X-hez kötött domináns öröklődésû betegséghez - csak lányokban fordulnak elő, mivel a hemizigóta fiú magzatokban letálisak [5]. Azonban már a MECP2-gén azonosításának évében, 1999-ben publikálták az első, fiúban előforduló esetet, amikor a súlyos klinikai kép (ismeretlen etiológiájú congenitalis encephalopathia, többszöri légzéskimaradás, korai halálozás) hátterében MECP2-mutáció igazolódott [6]. Azóta egyre több adat támasztja alá, hogy a fiúkban előforduló, $M E C P 2$-gént érintő mutáció nem feltétlenül okoz intrauterin elhalást, és az idegfejlődési betegségek széles spektrumaként manifesztálódhat $[7,8]$.

\section{Esetismertetés}

Intézetünkben egy 19 hónapos, pszichomotoros fejlődésében súlyosan elmaradt, kéthetes kora óta intraktábilis epilepszia miatt gondozott fiúgyermeket vizsgáltunk.

Családi anamnézise negatív, két idősebb fiútestvére egészséges. III/3. zavartalan terhességből, a 38. gesztációs hétre, 3680 g testsúllyal, megelőző császármetszés miatt sectio caesareával született. Cardiorespiratoricus adaptációja zavartalan volt.
Rohamai kezdetben váltott végtagú myoclonisatiónak, spasmusnak, majd fokális tónusos rohamoknak voltak megfeleltethetők. A rohamok gyógyszeres terápiára teljesen rezisztensek voltak. Az EEG-vizsgálatok kezdetben burst suppression mintázatot, majd szakaszos hypsarrhythmiát mutattak. A klinikailag korai kezdetű epilepsziás encephalopathia szindróma etiológiai hátterét tisztázandó kiterjedt klinikai vizsgálatok történtek. A koponya-MR-vizsgálat aspecifikus enyhe agyi atrófiát írt le. A szérum, a vizelet és a liquor anyagcsere-betegségek irányában történő vizsgálata szintén negatív eredményt adott.

Vizsgálatakor a kisdeddel rövid szemkontaktuson kívül kapcsolatot nem lehetett teremteni, aktív mozgás, beszéd nem alakult ki. Számos alkalommal jelentkeztek fokális tónusos rohamai, illetve percenként láttunk myoclonisatióval, összerezdüléssel járó görcsöket. Lényegi dysmorphiát nem észleltünk.

\section{Módszer}

A Pécsi Tudományegyetem Orvosi Genetikai Intézetének genetikai tanácsadójában részletes fenotípuselemzést végeztünk. A beteg törvényes képviselőjét a humángenetikai törvénynek megfelelően genetikai tanácsadásban részesítettük, ezt követően írásos beleegyezését adta a genetikai vizsgálatok elvégzéséhez. A DNS-minta tárolása, a vizsgált személy eredményeinek tudományos közleményben történő felhasználása az Egészségügyi Tudományos Tanács Tudományos és Kutatásetikai Bizottságának jóváhagyásával történt, a helsinki nyilatkozat (1971) irányelveit követtük.

A molekuláris genetikai vizsgálatokhoz EDTA-val alvadásgátolt perifériás leukocytákból E.Z.N.A. ${ }^{\circledR}$ Blood DNA Maxiprep Kit-tel (VWR International Kft., Debrecen) izolált genomiális DNS-mintát használtunk.

A beteg DNS-mintáját külföldi laboratóriumba (GENDIA - Genetic Diagnostic Network, Antwerpen, Belgium) küldtük ki egy 128 gént magában foglaló, újgenerációs szekvenálással (NGS) történő panelvizsgálat céljából epilepsziás encephalopathiát okozó betegségek irányában, melyhez a Nemzeti Egészségbiztosítási Alapkezelőtől igényeltünk egyedi támogatást.

A szülők hordozósági vizsgálatát a Pécsi Tudományegyetem Orvosi Genetikai Intézetének molekuláris genetikai laboratóriumában végeztük. A vizsgálat során mindkét szülő esetében célzottan a MECP2-gén c.1360as pozíciót magában foglaló régióját amplifikáltuk laboratóriumunkban tervezett, a régióra specifikus primerpár felhasználásával, PCR alkalmazásával. Az amplifikációt követően a PCR során keletkezett DNS-fragmentek nukleotidsorrendjének meghatározása direkt szekvenálással, didezoxi láncterminációs módszerrel, bidirekcionálisan, Applied Biosystems 3500 Genetic Analyzer automata szekvenáló (Thermo Fisher Scientific, Waltham, MA, Amerikai Egyesült Államok) segítségével történt meg. 


\section{Eredmények}

Betegünknél a 128 gént magában foglaló, epilepsziás encephalopathiát okozó betegségek irányában történt NGS-panelvizsgálat során a MECP2-génben egy hemizigóta c.1360G >C misszensz eltérést detektáltak, mely glicin-arginin-cserét okoz a fehérje 454-es aminosavpozíciójában (p.Gly454Arg). A talált eltérés a szakirodalomban eddig ismeretlen, különböző predikciós szoftverekkel (SIFT, Mutation Taster, PolyPhen-2) vizsgálva azonban patogén megítélésű, a külföldi laboratórium beszámolójában VUS-ként (variant with unknown significance) klasszifikált. A MECP2-génben detektált eltérést betegünk fenotípusával összevetve a szakirodalomban neonatalis súlyos encephalopathia néven ismert diagnózis állítható fel. A szülők hordozósági vizsgálata során az édesapa a vizsgált mutációra nézve normál genotípusúnak bizonyult, míg a tünetmentes édesanyánál heterozigóta formában kimutattuk a fiúgyermekénél észlelt c.1360G>C misszensz mutációt a MECP2-génben.

\section{Megbeszélés}

A korai kezdetú epilepsziás encephalopathia klinikai tüneteit mutató fiúbeteg etiológiai diagnózisához újgenerációs molekuláris genetikai vizsgálattal jutottunk. A szülők vizsgálata során az édesanya hordozósága igazolódott, aki feltehetően az eltolódott X-inaktiváció miatt tünetmentes. A szakirodalomban ismert néhány hasonló familiáris eset [9]. A családot genetikai tanácsadás keretében tájékoztattuk az ismétlődési kockázatról, a praenatalis vizsgálatot felajánlottuk egy következő terhesség esetén.

A lányokban gyakrabban kimutatott MECP2-mutáció hátterében több tényező is szerepet játszik. Egyrészt lányokban a $M E C P 2$-gén mutációi a széles körben használt kritériumrendszer alapján klinikailag jól felismerhető típusos vagy atípusos Rett-szindróma tüneteiben nyilvánulnak meg. Fiúkban ugyanezen mutációk széles tünetspektrumot magukban foglaló betegségekként manifesztálódnak, így fiúk esetén jóval ritkábban gondolunk a MECP2-mutációk kóroki szerepére. Másrészt a MECP2gén mutációi többnyire de novo mutációk, melyek fóleg a rendkívül gyorsan osztódó ivarsejtekben, a spermiumokban jönnek létre. A mutálódott spermium pedig - mivel a MECP2-gén az X-kromoszómán helyezkedik el - csak beteg lánymagzatot hozhat létre. A fiúkban előforduló, MECP2-mutáció következtében kialakuló betegségek hátterében a jóval ritkábban előforduló, a petesejtben létrejövő de novo mutáció állhat, illetve, ahogy esetünkben is, előfordulhat az édesanyától örökölt mutáció is.

A MECP2-gén mutációi fiúkban idegfejlődési kórképek széles spektrumában nyilvánulnak meg, és a lányokban látott, a Rett-szindrómára egyébként jellemző tünetek csak ritkán jelennek meg. Neul és mtsai 30, MECP2-mutációt hordozó fiúbeteg retrospektív vizsgálatának összegzéseként megállapították, hogy a MECPmutációt hordozó fiúk 4 csoportba sorolhatók: (1) klasz- szikus Rett-fenotípus csak szomatikus mutációt hordozó betegekben fordult elő, (2) súlyos neonatalis encephalopathia, (3) súlyos értelmi akadályozottság volt észlelhető a betegek felében, a betegek nagy többsége (4) a lányokban jelentkezőnél súlyosabb kórlefolyású atípusos Rettfenotípust mutatott. Az utóbbit új diagnosztikus entitásként fiúkban előforduló Rett-encephalopathiaként kategorizálták [10]. Fontos tehát elkülöníteni a MECP2mutáció következtében fiúkban és lányokban létrejövő klinikai képet: fiúkban nem a típusos Rett-szindróma klinikai képével találkozunk, a kialakuló tünetek általában jóval súlyosabbak, és változatosabb formában jelentkeznek.

Az újgenerációs szekvenálási módszerek elterjedésével fokozatosan növekszik az epilepsziás encephalopathiával összefüggésbe hozható gének száma, melyek megismerésével egyre mélyebb betekintést kaphatunk a betegség neurobiológiai hátterébe: 'csatornapátia', szinaptikus diszfunkció, transzporterdefektus, transzkripciódiszreguláció, károsodott DNS-javító mechanizmus, kromatinremodelling mind szerepet játszik a betegség patomechanizmusában.

Az általunk bemutatott beteg esete is jól reprezentálja, hogy a MECP2-génben létrejövő mutációk fiúmagzatokban nem minden esetben letálisak, a lányokban észlelhetőtől jelentősen különböző és súlyosabb fenotípust alakítanak ki, például a bemutatott neonatalis súlyos encephalopathiát.

Tekintettel az epilepsziás encephalopathia genetikai heterogenitására, más szerzőkkel egyetértésben úgy gondoljuk, hogy az újgenerációs szekvenálási technikáknak létjogosultságuk van az ismeretlen etiológiájú epilepsziás encephalopathia kivizsgálásában [11].

Anyagi támogatás: Ez a munka az OTKA K119540, GINOP-2.3.2-15-2016-00039, EFOP 3.6.1-16-201600004, valamint NKFI PD115677 támogatásával jött létre.

Szerzôi munkamegosztás: D. A. és T. Á. a klinikai részt és a megbeszélést, B. Zs. a módszereket és az eredményeket bemutató részt írta. A molekuláris genetikai vizsgálatokat és az eredmények kiértékelését $B$. Zs. végezte. H. K. és H. M. vizsgálta a beteget, H. K. és M. B. véleményezte és javította a kéziratot. A cikk végleges változatát valamennyi szerző elolvasta és jóváhagyta.

Érdekeltségek: A szerzőknek nincsenek érdekeltségeik.

\section{Irodalom}

[1] Neul JL, Kaufmann WE, Glaze DG, et al. Rett syndrome: revised diagnostic criteria and nomenclature. Ann Neurol. 2010; 68: 944-950.

[2] Zachariah RM, Rastegar M. Linking epigenetics to human disease and Rett syndrome: the emerging novel and challenging concepts in MECP2 research. Neural Plast. 2012; 2012: 415825. 
[3] Krishnan K, Lau BY, Ewall G, et al. MECP2 regulates cortical plasticity underlying a learned behaviour in adult female mice. Nat Commun. 2017; 8: 14077.

[4] Na ES, Monteggia LM. The role of MeCP2 in CNS development and function. Horm Behav. 2011; 59: 364-368.

[5] Hagberg B, Aicardi J, Dias K, et al. A progressive syndrome of autism, dementia, ataxia, and loss of purposeful hand use in girls: Rett's syndrome: report of 35 cases. Ann Neurol. 1983; 14: 471-479.

[6] Wan M, Lee SS, Zhang X, et al. Rett syndrome and beyond: recurrent spontaneous and familial MECP2 mutations at CpG hotspots. Am J Hum Genet. 1999; 65: 1520-1529.

[7] Reichow B, George-Puskar A, Lutz T, et al. Brief report: systematic review of Rett syndrome in males. J Autism Dev Disord. 2015; 45: 3377-3383.
[8] Villard L. MECP2 mutations in males. J Med Genet. 2007; 44: $417-423$

[9] Zhang Q, Zhao Y, Bao X, et al. Familial cases and male cases with MECP2 mutations. Am J Med Genet B Neuropsychiatr Genet. 2017; 174: 451-457.

[10] Neul JL, Benke TA, Marsh ED, et al. The array of clinical phenotypes of males with mutations in methyl-CpG binding protein 2 . Am J Med Genet B Neuropsychiatr Genet. 2019; 180: 55-67.

[11] McTague A, Howell KB, Cross JH, et al. The genetic landscape of the epileptic encephalopathies of infancy and childhood. Lancet Neurol. 2016; 15: 304-316.

(Till Ágnes dr., Pécs, József Attila u. 7., 7623 e-mail: till.agnes@pte.hu)

\section{PÁLYÁZAT}

A Prof. Dr. Romics László Akadémikus Emlékére Alapítvány pályázatot hirdet Magyarországon dolgozó, magyar állampolgárságú, 40 éven aluli orvosok és orvosbiológiai kutatással foglalkozó személyek számára. A nyertes pályázó(k) között $500000 \mathrm{Ft}$ alapítványi adomány kerül kiosztásra.

A pályázat célja: a klinikai gyógyítás vagy orvosi tudományos kutatás területén dolgozók kiemelkedő tudományos tevékenységének elismerése.

Előnyt élveznek azok a pályázók, akik az alapítvány névadójának munkásságát folytatva cardiovascularis és anyagcsere-betegségek területéről nyújtanak be pályázatot.

A pályázat benyújtásának határideje: 2020. január 31. (elbírálásának határideje: 2020. április 30.)

A pályázatot a palyazat@romicsalapitvany.hu e-mail címre pdf formátumban kell benyúitani.

A pályázatot természetes személy, saját nevében, magyar nyelven nyújthatja be, a pályázati anyag ábrák nélkül maximum 15000 leütés (karakter) terjedelmű lehet. A pályázathoz mellékelni kell egy rövid szakmai életrajzot a születési év megjelölésével.

A pályázat benyújtását saját kézzel aláírt és dátummal ellátott levélben kell bejelenteni az alapítvány titkárának címezve (a borítékra írandó cím: dr. Dudás Márta, 1461 Budapest, Pf. 62) könyvelt (ajánlott) küldeményben, mert ezen bejelentés alapján válik hitelessé a pályázat. A pályázatot nyomtatott formában nem kell mellékelni.

Az alapítvány adatairól, működéséről a www.romicsalapitvany.hu honlapon található információ.

A cikk a Creative Commons Attribution 4.0 International License (https://creativecommons.org/licenses/by/4.0/) feltételei szerint publikált Open Access közlemény, melynek szellemében a cikk bármilyen médiumban szabadon felhasználható, megosztható és újraközölhető, feltéve, hogy az eredeti szerző és a közlés helye, illetve a CC License linkje és az esetlegesen végrehajtott módositások feltüntetésre kerülnek. (SID_1) 